\title{
Oral management of a patient with down syndrome and agammaglobulinemia: a case report
}

\author{
Yasuka Kusumoto $^{1 *}$, Kohsuke Imai $^{2}$, Yoshio Ohyama ${ }^{3}$, Haruhisa Fukayama $^{4}$ and Osamu Shinozuka ${ }^{1}$
}

\begin{abstract}
Background: Down syndrome is characterized by a variety of dysmorphic features and congenital malformations, such as congenital heart disease, gastrointestinal disease, and other conditions like leukemia and autoimmune disorders. Patients with Down syndrome are highly prone to respiratory tract infections, which might be fatal to them. However, there are only few available data on patients diagnosed with Down syndrome and agammaglobulinemia. In this report, we describe a case of successful prevention of post-dental treatment complications (e.g., pneumonia and other bacterial infections) in a patient with Down syndrome and agammaglobulinemia.
\end{abstract}

Case presentation: A 43-year-old man with Down syndrome, untreated agammaglobulinemia, and a history of recurrent pneumonia, was referred to our clinic for tooth mobility. To reduce the risk of post-operative infections, gammaglobulin treatment and prophylactic administration of antibiotics was scheduled before the dental procedure. Furthermore, the dental treatment, which included a filling and extractions, was conducted under general anesthesia and with the supervision of a hematologist. The dental procedures were successfully performed without any post-operative infection, and the patient is undergoing follow-up care.

Conclusions: The purpose of this case report was to recommend a close liaison between physicians and dentists who may encounter a similar case, and to emphasize the importance of improving oral health of immunodeficient patients to prevent infections caused by oral microbial flora.

Keywords: Down syndrome, Immunodeficiency, Oral management, Case report

\section{Background}

Down syndrome is characterized by a variety of dysmorphic features and congenital malformations, such as congenital heart disease, gastrointestinal disease, and other conditions like leukemia and autoimmune disorders. Patients with Down syndrome are highly prone to respiratory tract infections, which constitute the most important cause of mortality in such patients at all ages

\footnotetext{
* Correspondence: yasu.dpd@tmd.ac.jp

'Department of Dentistry for Persons with Disabilities, Graduate School of Medical and Dental Sciences, Tokyo Medical and Dental University, 1-5-45, Yushima, Bunkyo-ku, Tokyo, Japan

Full list of author information is available at the end of the article
}

$[1,2]$. Agammaglobulinemia is one of the most common primary immunodeficiency disorders, and is characterized by the absence of immunoglobulins. In 1952, Bruton was the first physician to describe a clinical case of absence of immunoglobulins [3]. The diseases of primary antibody deficiency (PAD) represent a class of disorders in humans in which a defective immune system fails to produce antibodies. Patients with PAD generally have low levels of immunoglobulin (Ig) A, IgG, or IgM. PAD is associated with frequent infections of the respiratory tract, skin, sinuses, and lungs. Therefore, there is a high risk of infection during dental treatment in a patient with PAD. However, there is no report of dental

(c) The Author(s). 2020 Open Access This article is licensed under a Creative Commons Attribution 4.0 International License, which permits use, sharing, adaptation, distribution and reproduction in any medium or format, as long as you give appropriate credit to the original author(s) and the source, provide a link to the Creative Commons licence, and indicate if changes were made. The images or other third party material in this article are included in the article's Creative Commons licence, unless indicated otherwise in a credit line to the material. If material is not included in the article's Creative Commons licence and your intended use is not permitted by statutory regulation or exceeds the permitted use, you will need to obtain permission directly from the copyright holder. To view a copy of this licence, visit http://creativecommons.org/licenses/by/4.0/. The Creative Commons Public Domain Dedication waiver (http://creativecommons.org/publicdomain/zero/1.0/) applies to the data made available in this article, unless otherwise stated in a credit line to the data. 
treatment in patients with Down syndrome diagnosed with agammaglobulinemia.

Here, we report the successful prevention of postdental treatment complications, such as pneumonia and other bacterial infections, in a 43-year-old man with Down syndrome and agammaglobulinemia, through immunoglobulin administrations and prophylactic antibiotherapy.

\section{Case presentation}

Consent for publication in this report was obtained from the patient's mother.

A 43-year old male patient was referred to the Clinic for Persons with Disabilities at the Dental Hospital of Tokyo Medical and Dental University (Tokyo, Japan) with a primary complaint of tooth mobility. He had a history of Down syndrome that was diagnosed at birth. He lived alone with his mother. Family history was unremarkable. He had experienced recurrent pneumonia and chronic bronchitis since he was 34 years old. Subsequent immunological assessment revealed agammaglobulinemia (Fig. 1) and B-cell deficiency (0.47\%) associated with decreased CD45 RA+ naive CD4+ T-cells (4.5\% of CD4+ T-cells) (Fig. 2). He had never received gammaglobulin treatment.

Oral and radiographic examinations revealed alveolar bone resorption in maxillary incisors and several decayed teeth (Fig. 3). Marginal gingivitis was observed all around the teeth. The patient's oral hygiene was very poor with dental plaque on all surfaces of his teeth.

The patient had severe mental retardation and autistic features, which included difficulty in communication. Thus, with the consent of his family, it was decided to perform a comprehensive evaluation and treatment under general anesthesia as an in-patient procedure. After consultation with a hematologist, the patient received three courses of intravenous immunoglobulin (IVIG) therapy to restore and maintain his serum IgG levels above $500 \mathrm{mg} / \mathrm{dL}$ (Fig. 1). IVIG therapy was implemented at 4 weeks, 2 weeks, and 1 day before operation.

The mandibular right first molar was restored with light-cured composite resin. The maxillary left first molar, second molar, maxillary incisors, and mandibular left incisor were extracted. After extraction, sockets were sutured to prevent post-operative infection. Suture reduced the risk of rebleeding and relieved patient discomfort.

Operating table was prepared in the usual fashion. For operative field, we used $0.025 \%$ benzalkonium chloride solution and normal saline solution as usual. All procedures were carried out under standard disinfection without any additional measures.

Ampicillin sodium (6g/day) was administered every $12 \mathrm{~h}$ intravenously, beginning in the morning before the operation and then for 4 days after the operation, following which the patient was discharged without any infection or complication.

At present, the patient is undergoing follow-up care, and the marginal gingivitis has improved. He is receiving regular IVIG treatments under the care of his local physician.

\section{Discussion}

The case reported here was successfully managed through the administration of gammaglobulin and antibiotics. This report describes the management of

\begin{tabular}{|c|c|c|c|c|c|c|}
\hline & & First visit & $\begin{array}{c}4 \text { weeks } \\
\text { before operation }\end{array}$ & $\begin{array}{c}3 \text { weeks } \\
\text { before operation }\end{array}$ & $\begin{array}{c}2 \text { weeks } \\
\text { before operation }\end{array}$ & $\begin{array}{c}1 \text { day } \\
\text { before operation }\end{array}$ \\
\hline & WBC & 12500 & & 6970 & 6200 & 4800 \\
\hline & RBC & 545 & & 472 & 426 & 465 \\
\hline & $\mathrm{Hb}$ & 17 & & 14.7 & 13.4 & 14.7 \\
\hline & Plt & 21.4 & & 26 & 13.4 & 26.2 \\
\hline & IgG & 49 & & & 265 & 530 \\
\hline & $\operatorname{Ig} A$ & 4 & & & & 5 \\
\hline & IgM & 4 & & & & 3 \\
\hline & & IVIG & $15 \mathrm{~g}$ & & $1 \bar{g} \mathrm{~g}$ & $1 \bar{g} g$ \\
\hline $\begin{array}{l}\text { Fig. } 1 \text { Schedule o } \\
\text { lgG }=\text { immunoglot } \\
(10,000 / \mu \mathrm{L}) ; \mathrm{RBC}=\end{array}$ & $\begin{array}{l}\text { pre-operati } \\
\text { alin G (mg/c } \\
\text { ed blood ce }\end{array}$ & $\begin{array}{l}\text { enous immun } \\
=\text { immunoglo } \\
(10,000 / \mu \mathrm{L}) ; \mathrm{V}\end{array}$ & $\begin{array}{l}\text { globulin (IVIG) the } \\
\text { ulin M (mg/dL); IVI } \\
B C=\text { white blood }\end{array}$ & $\begin{array}{l}\text { erapy. } \mathrm{Hb}=\text { hemo } \\
/ \mathrm{IG}=\text { intravenous i } \\
\text { cell count }(/ \mu \mathrm{L})\end{array}$ & $\begin{array}{l}\text { lobin level }(\mathrm{g} / \mathrm{dl} \\
\text { mmunoglobulin }\end{array}$ & $\begin{array}{l}\text { IgA } \mathrm{A}=\text { immunoglo } \\
\text { bstitution; Plt = pl }\end{array}$ \\
\hline
\end{tabular}



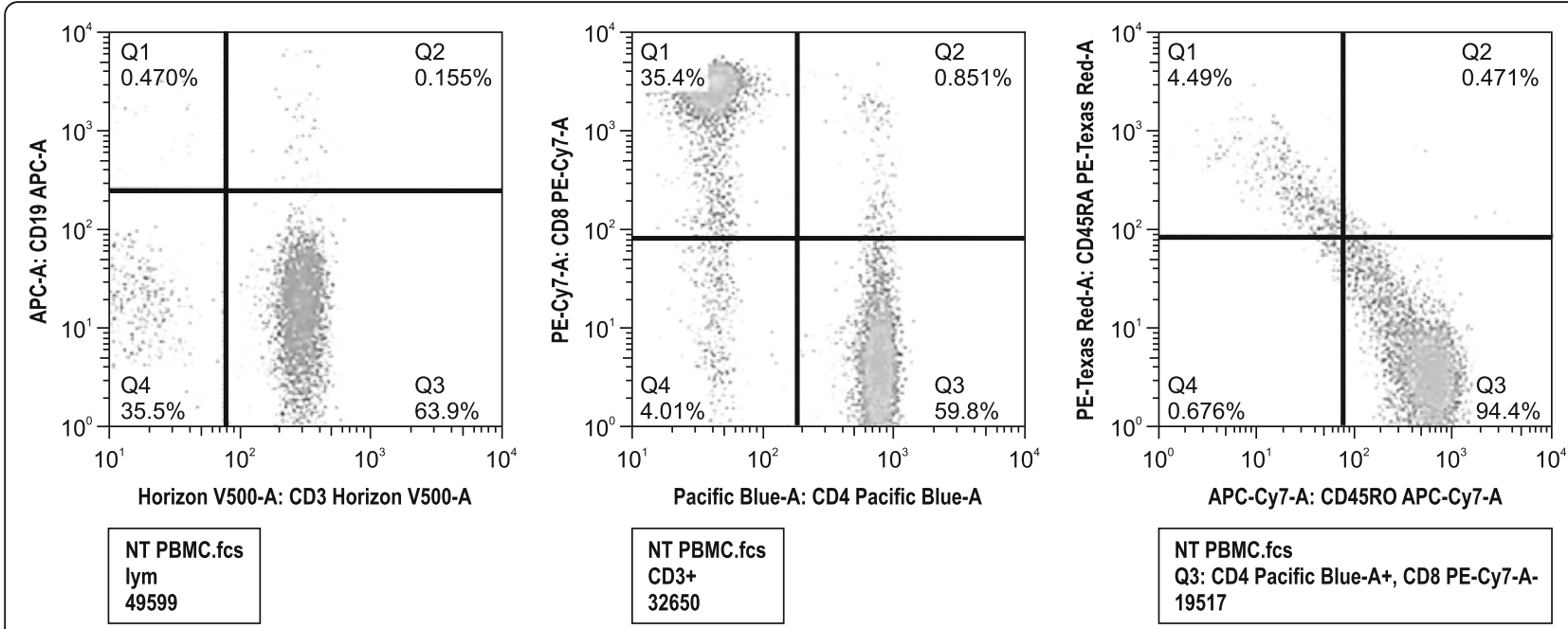

Fig. 2 Flow cytometric analysis of the patient's peripheral blood mononuclear cells (PBMCs). PBMCs from the patient were stained with monoclonal antibodies for CD19, Cd3, CD4, CD45RA, and CD45RO. The B-cells and naive T-cells were remarkably decreased in the patient

agammaglobulinemia in a patient with Down syndrome during oral care procedures. Autoimmune diseases are frequently observed in patients with Down syndrome, with prevalence of immune deficiency, mild to moderate T-cell and B-cell lymphopenia with decreased naive lymphocytes, impaired mitogen-induced T-cell proliferation, reduced specific antibody responses to immunizations, and defects in neutrophil chemotaxis $[4,5]$. These abnormalities may contribute to increased susceptibility to viral infections, hematologic malignancies, and autoimmune diseases associated with Down syndrome $[4,5]$. For invasive dental procedures, such patients are at a high risk of severe infection and septicemia caused by the spread of oral microorganisms and their toxins through circulating blood. Clinical use of IVIG therapy has increased in the treatment of patients with PADS.
IVIG therapy in patients with agammaglobulinemia reduces the risk of infection [6, 7]. It involves therapeutic preparations of pooled polyspecific IgG, obtained from the plasma of a large number of healthy individuals. IVIG approach had a significant and positive therapeutic impact in our patient (Fig. 1).

IVIG therapy prevents many, though not all, pulmonary complications. Though they are receiving IVIG therapy, in some patients with relatively more severe antibody deficiencies, may be in high risk of chronic bacterial infections [8]. Then a standard course of antibiotics for acute infections stemming from surgical treatment would not be sufficient in severely immunodeficient patients and may lead to rapid relapse or recurrence of infections and further morbidity, including permanent scarring and loss of function. Experienced

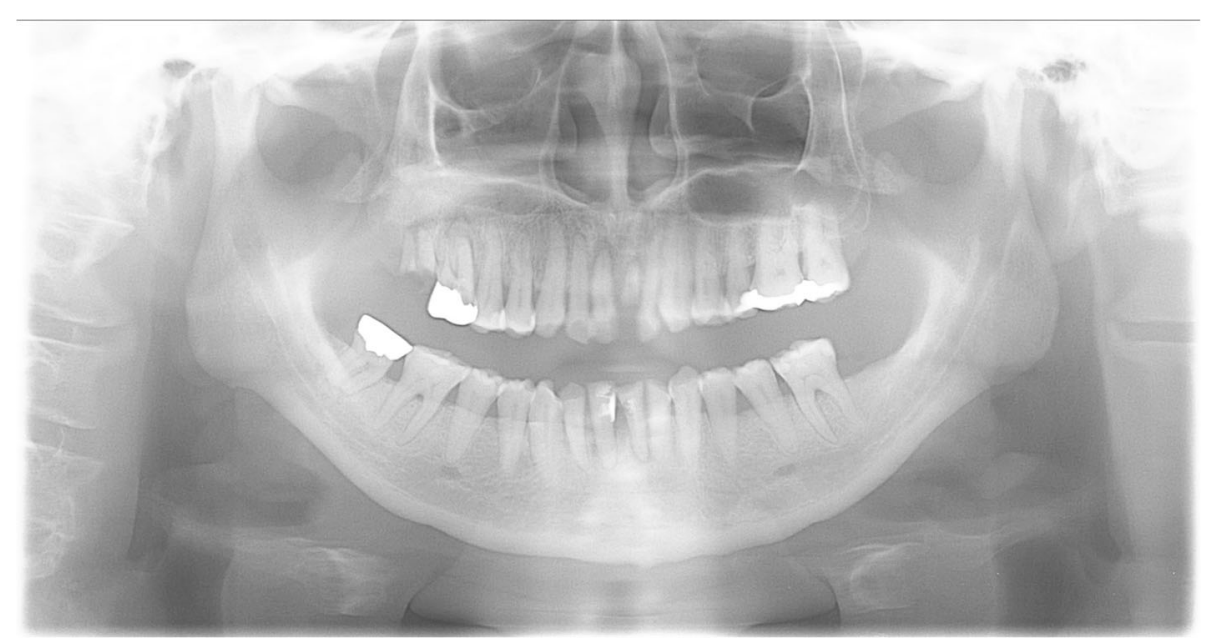

Fig. 3 Panoramic radiograph, radiographic examinations revealed alveolar bone resorption in maxillary incisors and several decayed teeth 
clinical immunologists often prescribe a course of antimicrobials that are two to three times longer than standard recommendations $[9,10]$. In the case described here, antibiotic prophylaxis besides the induction of IVIG treatment was effective for dental treatment of the immunodeficient patient.

Owing to their susceptibility to infection, immunodeficient patients require precautions during dental treatment. Dental treatment of patients with severe combined immunodeficiency has not been previously reported in dental or medical literature. Based on our experience with this patient, we recommend that IgG, IgA, and IgM should be evaluated in patients with Down syndrome before they undergo dental procedures. Delayed diagnosis of agammaglobulinemia and other PADs might result in frequent hospitalizations owing to bacterial infections, including pneumonia, which could lead to chronic lung diseases.

In the current case, initial oral examination revealed poor oral hygiene. Home care is essential for a patient's oral hygiene and dental health. However, this is difficult to achieve in patients with Down syndrome owing to the intellectual impairment and decreased manual dexterity [11]. Since patients with Down syndrome frequently experience respiratory infections, regular oral and dental examination should be performed to reduce the risk of aspiration pneumonia; it should be remembered that as they age, people with Down syndrome are more likely to present with immune deficiency syndromes related to early senescence [12] and innate abnormalities in the immune response. Physicians and dentists should take exceptional precautions to detect oral pathogens in these patients, since the pathogens may result in pneumonia and other severe infection. Early diagnosis and treatment, including IVIG, is essential to improve prognosis and quality of life of patients with PADs [13]. In addition, if possible, newborn mass screening for PADs is recommended [14-17].

\section{Conclusions}

The purpose of this case report was to recommend a close liaison between physicians and dentists who may encounter a similar case, and to emphasize the importance of periodontal health in immunodeficient patients to prevent infections caused by oral microbial flora.

\section{Abbreviations \\ IgA: Immunoglobulin A; IgG: Immunoglobulin G; IgM: Immunoglobulin M; IVIG: Intravenous immunoglobulin; PAD: Primary antibody deficiency}

\section{Acknowledgements}

Not applicable.

\section{Authors' contributions}

$\mathrm{KI}$ analyzed and interpreted the patient data regarding the hematological disease. YO performed surgical procedures. HF contributed to evaluation and administration of general anesthesia. KY and OS performed dental treatment and were major contributor in writing the manuscript. The authors read and approved the final manuscript.

Funding

Not applicable.

Availability of data and materials

The datasets generated and analyzed during the current study are not publicly available since they contain medical information of the patient.

Ethics approval and consent to participate

Not applicable.

\section{Consent for publication}

Written and signed consent to publish the images in this case report was obtained from the mother of the patient. A copy of the consent is available for review by the Editor of this journal.

\section{Competing interests}

The authors declare that they have no competing interests.

\section{Author details}

'Department of Dentistry for Persons with Disabilities, Graduate School of Medical and Dental Sciences, Tokyo Medical and Dental University, 1-5-45, Yushima, Bunkyo-ku, Tokyo, Japan. ${ }^{2}$ Department of Community Pediatrics, Perinatal and Maternal Medicine, Graduate School of Medical and Dental Sciences, Tokyo Medical and Dental University, Tokyo, Japan. ${ }^{3}$ Department of Oral and Maxillofacial Surgery, Shizuoka City Shizuoka Hospital, Shizuoka, Japan. ${ }^{4}$ Department of Anesthesiology and Clinical Physiology, Graduate School of Tokyo Medical and Dental University, Tokyo, Japan.

Received: 30 December 2019 Accepted: 2 March 2020

Published online: 13 March 2020

\section{References}

1. Bloemers BL, Broers CJ, Bont L, Weijerman ME, Gemke RJ, van Furth AM. Increased risk of respiratory tract infections in children with Down syndrome: the consequence of an altered immune system. Microbes Infect. 2010:12:799-08.

2. Pérez JAH, Hernandez Guerra JS. Community-acquired pneumonia in adults with Down syndrome. Three clinical cases and a review of the literature. Rev Med Int Sindr Down. 2010;14:25-30.

3. Bruton OC. Agammaglobulinemia. Pediatrics. 1952:9:722-8.

4. Ram G, Chinen J. Infections and immunodeficiency in Down syndrome. Clin Exp Immunol. 2011;164:9-16.

5. Kusters MA, Verstegen RH, Gemen EF, de Vries E. Intrinsic defect of the immune system in children with Down syndrome: a review. Clin Exp Immunol. 2009;156:189-93.

6. Furst DE. Serum immunoglobulins and risk of infection: how low can you go? Semin Arthritis Rheum. 2008;39:18-29.

7. Aghamohammadi A, Moin M, Farhoudi A, Rezaei N, Pourpak Z, Movahedi M, et al. Efficacy of intravenous immunoglobulin on the prevention of pneumonia in patients with agammaglobulinemia. FEMS Immunol Microbiol. 2004:40:113-8

8. Hernandez-Trujillo VP. Agammmaglobulinemia: Up to Date, https://www. uptodate.com/contents/primary-immunodeficiency-overview-ofmanagement?sectionName=ANTIMICROBIAL\%20THERAPY\&topicRef=3931 \&anchor $=$ H700594245\&source $=$ see link\#.

9. Stiehm RE. Primary immunodeficiency: Overview of management. Up to Date, https://www.uptodate.com/contents/primary-immunodeficiencyoverview-of-management?sectionName=ANTIMICROBIAL\%2 OTHERAPY\&topicRef $=3931$ \&anchor $=$ H700594245\&source $=$ see_link\#H7005 94245.Accessed 1 May 2019.

10. Driessen $\mathrm{G}$, van der Burg M. Educational paper: primary antibody deficiencies. Eur J Pediatr. 2011:170:693-02.

11. Pilcher E. Dental care for the patient with Down syndrome. Down Syndr Res Practice. 1998:5:111-6.

12. Bloemers BL, van Bleek GM, Kimpen $J$, Bont $L$. Distinct abnormalities in the innate immune system of children with Down syndrome. J Pediatr. 2010; 156:804-9. 
13. Shehata N, Palda V, Bowen T, Haddad E, Issekutz TB, Mazer B, et al. The use of immunoglobulin therapy for patients with primary immune deficiency. An evidence-based practice guideline. Transfus Med Rev. 2010;24:S28-50.

14. Kwan A, Abraham RS, Currier R, Brower A, Andruszewski K, Abbott JK, et al. Newborn screening for severe combined immunodeficiency in 11 screening programs in the United States. JAMA. 2014;312:729-38.

15. Kamae C, Nakagawa N, Sato H, Honma K, Mitsuiki N, Ohara O, et al. Common variable immunodeficiency classification by quantifying T-cell receptor and immunoglobulin $\mathrm{k}$-deleting recombination excision circles. J Allergy Clin Immunol. 2013;131:1437-40 e5.

16. Nakagawa N, Imai K, Kanegane H, Sato H, Yamada M, Kondoh K, et al. Quantification of k-deleting recombination excision circles in Guthrie cards for the identification of early B-cell maturation defects. J Allergy Clin Immunol. 2011;128:223-5e2.

17. Michela B, Annika O, Stephan B, Susanne J, Rolf HZ, Jovanka K, et al. Newborn screening for severe primary immunodeficiency diseases in Sweden-a 2-year pilot TREC and KREC screening study. J Clin Immunol. 2017;37:51-60

\section{Publisher's Note}

Springer Nature remains neutral with regard to jurisdictional claims in published maps and institutional affiliations.

Ready to submit your research? Choose BMC and benefit from:

- fast, convenient online submission

- thorough peer review by experienced researchers in your field

- rapid publication on acceptance

- support for research data, including large and complex data types

- gold Open Access which fosters wider collaboration and increased citations

- maximum visibility for your research: over $100 \mathrm{M}$ website views per year

At BMC, research is always in progress.

Learn more biomedcentral.com/submissions 